\title{
Expression of Wild-Type p53 by Curcumin, Alpinetin and Flavokawain B in Colorectal Cancer cells Expressing R273H Mutant p53
}

\author{
${ }^{*} 1,5$ I. Malami, ${ }^{2}$ A. Muhammad, 3.B. Abubakar, ${ }^{4}$ A.M. Alhassan \\ 1Department of Pharmacognosy and Ethnopharmacy, Faculty of Pharmaceutical Sciences, Usmanu Danfodiyo University, PMB 2346, \\ Sokoto, Nigeria \\ 2Department of Biochemistry, Faculty of life Sciences, Ahmadu Bello University, Zaria, Nigeria \\ ${ }^{3}$ Department of Biochemistry, Faculty of life Sciences, Kebbi State University of Science and Technology, Aliero, Nigeria. \\ ${ }^{4}$ Department of Pharmaceutical and Medicinal Chemistry, Faculty of Pharmaceutical Sciences, Usmanu Danfodiyo University, Sokoto, \\ Nigeria \\ ${ }^{5}$ Centre for Advance Medical Research and Training, Usmanu Danfodiyo University, PMB 2346, Sokoto, Nigeria \\ [Corresponding Author: E-mail: Ibrahim.malami@udusok.edu.ng; E: +2348166923199]
}

\section{ABSTRACT}

A mutation in p53 is frequently reported in nearly $50 \%$ of all of human cancers arising from DNA-binding core domain of $p 53$. DNA-contact mutant $\mathrm{R} 273 \mathrm{H}$ rendered $\mathrm{p53}$ at dysfunctional state due to the substitution of single residue Arg273 for His273. Here, natural bioactive compounds curcumin, alpinetin and flavokawain B were investigated for possible stabilisation of wild-type p53 expression in vitro using HT-29 cells harbouring R273H rendered p53. Accordingly, all the bioactive compounds were able to induce the expression of wild-type p53 both at the levels of gene and protein expression. A dosedependent induction of p53 was evident at 12.5, 25 and $50 \mu \mathrm{M}$ concentration. The present study has shown that the bioactive compounds may have restored the wild-type p53 functional activity in tumour cells expressing R273H mutant p53.

Keywords: Curcumin, Alpinetin, Flavokawain B, p53, R273H

\section{INTRODUCTION}

The p53 is a tumour-suppressor protein critical for preventing cancer growth via transcriptional regulation of target genes associated with DNA repair, cell cycle checkpoints as well as apoptosis (Blandino and Agostino, 2018; Malami et al., 2017). In response to numerous stress signals, p53 is activated leading to a series of diverse anti-proliferative responses (Fridman and Lowe, 2003). Under normal conditions, the function of p53 is effectively regulated through the overexpression of human murine double minute 2 (MDM2) (Zhao et al., 2015). A mutation in p53 gene has been implicated in several tumours including colorectal cancer (Joerger and Fersht, 2016). A mutation in the wild-type p53, consequently rendered $p 53$ dysfunctional by failure to perform similar wild-type functions in executing transcriptional regulation of target genes that prevent cancer progression (Vijayakumaran et al., 2015). Consequently, mutant p53 protein becomes unsusceptible to MDM2 degradation, which accumulates in cancer cells and enhances oncogenic functions (Bykov et al., 2005).
Approximately, $50 \%$ of all of human cancers are reported to contain p53 mutations arising from DNA-binding core domain of p53, thereby disrupting the protein-DNA interaction (Tan et al., 2015). DNA-contact mutant $\mathrm{R} 273 \mathrm{H}$ rendered p53 at dysfunctional state resulting from substitution of single amino acid residue arginine for histidine at position 273 (Malami et al., 2017). We have recently reported a probable mechanistic study for possible restoration of wild-type p53 functional activities by small molecular weight natural products curcumin, alpinetin, and flavokawain B (Figure 1) using In Silico studies (Malami et al., 2017). In the study, we have anticipated that these bioactive compounds are capable of mediating a direct p53 reactivation via specific interaction with DNA binding core domain of R273H mutant p53. The present study therefore investigates the possible in vitro reactivation of wild-type p53 tumour-suppressor by the bioactive compounds; curcumin, alpinetin and flavokawain B in HT-29 cells harbouring $\mathrm{R} 273 \mathrm{H}$ mutant $\mathrm{p} 53$ protein. 
A

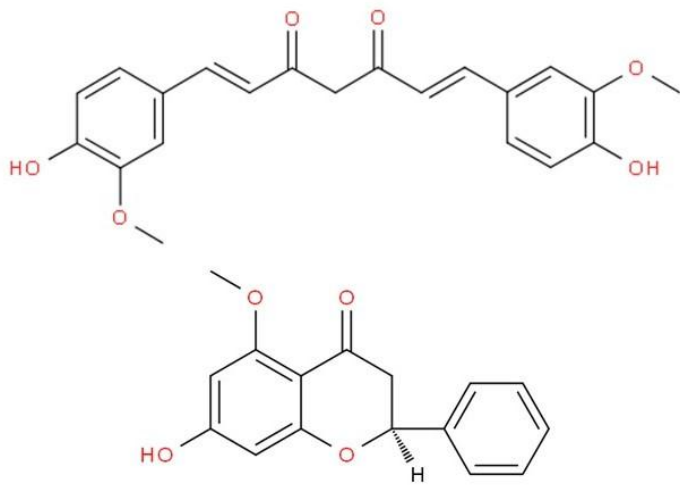

C

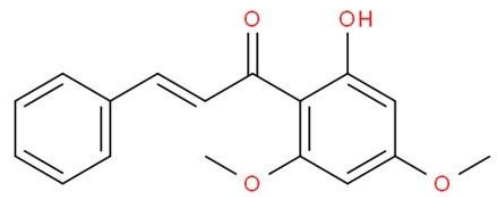

Figure 1: Chemical structure of $(A)$ Curcumin; $(B)$ Alpinetin; and (C) Flavokawain B.

\section{MATERIALS AND METHODS}

\section{Cell Culture}

A Human HT-29 cells (ATCC) were retrieved frozen from a liquid nitrogen storage tank of MAKNA-Cancer Research Laboratory and maintained in Dulbecco's Modified Eagle's Medium (DMEM) (Sigma-Aldrich, USA) containing 10\% Fetal Bovine Serum (FBS) (PAA, Germany) and $1 \%$ antibiotics (consist of $100 \mathrm{IU}$ penicillin and 100 $\mu \mathrm{g} / \mathrm{mL}$ streptomycin) (Sigma-Aldrich, USA). All cells were constantly maintained at $37^{\circ} \mathrm{C}$ inside a humidified incubator supplied with $5 \% \mathrm{CO}_{2}$. Cell culture was maintained by routine harvesting of cells with the aid of $0.05 \%$ trypsin-EDTA at the level of $70-80 \%$ confluence.

\section{Preparation of Test Compounds}

Alpinetin and flavokawain B were previously isolated from the rhizome of Alpinia mutica Roxb (Malami et al., 2016) and used for the present study, whilst curcumin (CU) (purity 97.35\%) was purchased from Sigma-Aldrich, USA. Stock solution for each compound was prepared at a concentration of $400 \mu \mathrm{M}$ in DMSO $(50 \mu \mathrm{L})$. Each calculated concentration contains $0.1 \%$ DMSO as the final concentration. Negative control was treated with $0.1 \%$ DMSO.

\section{Treatments}

HT-29 Colorectal cancer cells at a concentration of $0.5 \times 10^{4}$ were cultured in 6-well plates and incubated for $24 \mathrm{~h}$ to allow full attachment. Cells were subsequently treated at different concentrations with either curcumin $(12.5 \mu \mathrm{M}, 25$ $\mu \mathrm{M}$ and $50 \mu \mathrm{M})$, alpinetin $(12.5 \mu \mathrm{M}, 25 \mu \mathrm{M}$ and 50 $\mu \mathrm{M})$ or flavokawain $\mathrm{B}(12.5 \mu \mathrm{M}, 25 \mu \mathrm{M}$ and 50 $\mu \mathrm{M})$. Likewise, non-treated control cells were treated with $0.1 \%$ DMSO.

\section{RT-PCR Analysis of p53 mRNA}

Synthesis of cDNA from total RNA was performed using a RevertAid cDNA synthesis kit (Thermo Scientific, US) according to the manufacturer's recommendations. Briefly, approximately $1.0 \mu \mathrm{g}$ from total RNA, random hexamer, $5 \times$ reaction buffer, RNase inhibitor, $10 \mathrm{mM} \mathrm{dNTP}$, and RevertAid were collectively mixed in $200 \mu \mathrm{L}$ PCR tube. Total reaction volume was made to $20 \mu \mathrm{L}$ with nuclease-free water, gently mixed, centrifuged, and incubated in DNA thermal cycler at $25^{\circ} \mathrm{C}$ for $5 \mathrm{~min}$ followed by $42{ }^{\circ} \mathrm{C}$ for $60 \mathrm{~min}$. The reaction was terminated at $70^{\circ} \mathrm{C}$ for $5 \mathrm{~min}$ and kept at $4{ }^{\circ} \mathrm{C}$. A total of $20 \mu \mathrm{L}$ reaction volume containing cDNA template was amplified using Exprime Taq premix (Genet Bio, Daejeon, Korea). The cDNA template was amplified for $5 \mathrm{~min}$ at $94^{\circ} \mathrm{C}$ for one cycle, followed by 25 cycles for 30 sec at $48^{\circ} \mathrm{C}, 30 \mathrm{sec}$ at $47^{\circ} \mathrm{C}, 30 \mathrm{sec}$ at $72^{\circ} \mathrm{C}$, and final extension for $5 \mathrm{~min}$ at $72^{\circ} \mathrm{C}$ for one cycle. The p53 primer sequences used for PCR amplification are forward: 5'TGTGGAGTATTTGGATGACA-3' and reverse: 5'-GAACATGAGTTTTTTATGGC-3'.

\section{Extraction of Cell Lysate}

Treated and non-treated HT-29 cells were harvested using radioimmunoprecipitate assay (RIPA) buffer (Merck, Germany) supplemented with $10 \%$ protease inhibitor cocktail (Merck, Germany) and centrifuged at 20,000 $\mathrm{xg}$ for $10 \mathrm{~min}$ at $4{ }^{\circ} \mathrm{C}$ using Eppendorf microcentrifuge (Eppendorf, Germany). Cell lysate was aliquoted in $200 \mu \mathrm{L}$ tubes and kept frozen in a $-80^{\circ} \mathrm{C}$ storage until use. Protein content in the lysate was quantified using the Bradford protein assay. 


\section{Western Blot Analysis}

Briefly, $25 \mu \mathrm{g}$ of protein sample was separated by PowerPac ${ }^{\mathrm{TM}}$ electrophoresis (Bio-rad, USA) on an SDS-polyacrylamide gel followed by transfer of the separated proteins into a Polyvinylidene difluoride membrane (PVDF) (Bio-rad, USA) using semi-dry transblot Turbo (Bio-rad, USA). The membrane was incubated at room temperature with gentle agitation in 5\% non-fat dry milk (Bio-rad, USA) in Tris-buffered saline and Tween 20 (TBS-T). Membrane was washed for 3 consecutive times in TBS-T and incubated at room temperature for $2 \mathrm{~h}$ with either a labelled mouse anti- $\beta$-Actin (Santa Cruz, USA) or mouse anti-p53 (Biolegend, USA). Thereafter, the target protein was finally detected after labelling with horseradish peroxidaseconjugated Goat anti-mouse IgG (Biolegend, US) using ECL chemiluminescence (Thermo Scientific, USA) in ChemiDoc (Bio-rad, USA).

\section{RESULTS}

In the present study, the bioactive compounds were examined for their potential to induce the wild-type p53 expression using HT-29 cell line known to express R273H mutant p53. HT-29 cells treated with either curcumin, alpinetin, or flavokawain $B$ at different concentrations $(12.5,25$ and $50 \mu \mathrm{M}$ ) induced the expression of p53 mRNA when compared to HT-29 cells treated with DMSO used as a negative control.

In Figure $2 \mathrm{~A}$ and $2 \mathrm{~B}$, the expression levels of $\mathrm{p} 53$ gene were drastically increased in cells treated with curcumin and alpinetin at $25 \mu \mathrm{M}$ and subsequently decreased slightly at $50 \mu \mathrm{M}$. Whereas, the levels of p53 genes were expressed in a steady-state in the cells treated with flavokawain $B$ at $12.5,25$ and $50 \mu \mathrm{M}$. On the other hand, the expression of p53 protein in HT-29 cells treated with curcumin at different concentrations was prominent at 25 and $50 \mu \mathrm{M}$ when compared to the DMSO-treated control (Figure 2C). Likewise, a similar effect was sequentially visible in the presence of either alpinetin or flavokawain B (Figure 2D and 2E).

\section{DISCUSSION}

Amongst the hot spot mutation sites (Arg175, Gly245, Arg248, Arg249, Arg273, and Arg282) that are implicated in p53 mutation, DNA-contact mutant $\mathrm{R} 273 \mathrm{H}$ has been one of the five frequently observed in all human cancers (Joerger et al., 2006). DNA-contact mutant R273H is structurally classified under contact category of p53 mutation, which defines the direct interactions involving amino acid residues Arg248 and Arg273 and the DNA (Joerger et al., 2006).

Therefore, any mutation in these residues will lead to loss of contact with the DNA-binding surface. Consequently, such mutation has displayed increased resistance to antitumor agents, including very significantly used cisplatin (Li et al., 2014). Hence, targeting p53 mutation have become a recent drug target for development of novel therapeutics for cancer treatment.

In the present study, we tested and reported the effect of curcumin, alpinetin and flavokawain $B$ on the wild-type p53 status in HT-29 cells harbouring $\mathrm{R} 273 \mathrm{H}$ mutant $\mathrm{p53}$. We examined the expression of wild-type p53 mRNA to ensure the expression of the appropriate gene in the treated cells. The expected length of the PCR product of p53 CDNA was produced, which conform the target wild-type p53 mRNA. Furthermore, we found that all the bioactive compounds were able to induce the level of wild-type p53 mRNA expression after $72 \mathrm{~h}$ treatment as confirmed by densitometric analysis (Figure 2B). 

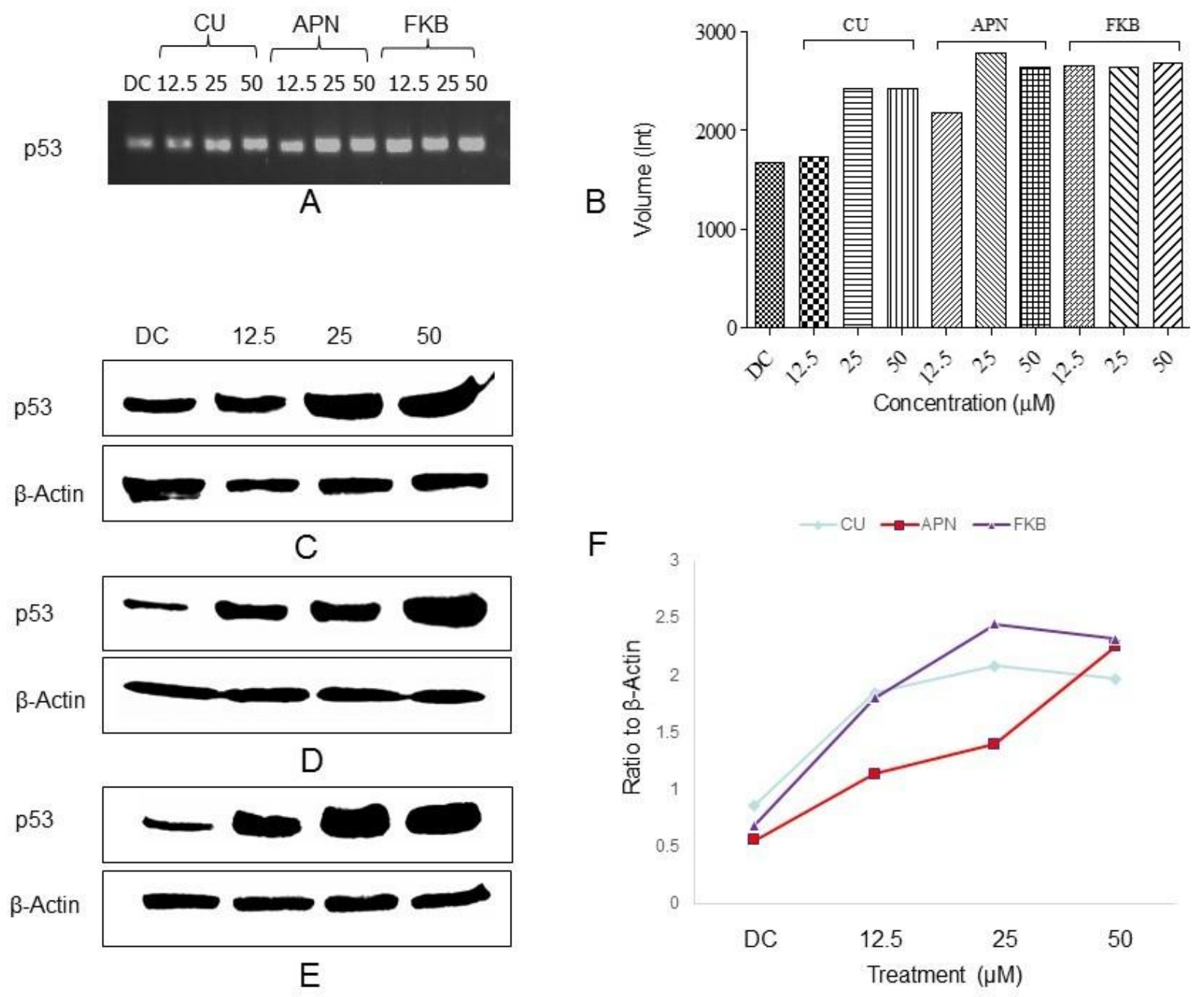

Figure 2: (A) Levels of p53 mRNA expression in HT-29 cells following treatment with curcumin, alpinetin and flavokawain B; (B) Graphical representation of p53 gene expressed in HT-29 cells; (C); (D); and (E) shows the levels of p53 protein expression in HT-29 cells following treatment with curcumin; alpinetin; and flavokawain B, respectively; $(F)$ Graphical representation of p53 protein expressed in HT-29 cells. CU: Curcumin; APN: alpinitin; FKB: flavokawain B; DL: DNA ladder; DC: DMSO treated control. All treatments are in $\mu \mathrm{M}$ concentration. Volume intensities of gel signals were analysed by GelAnalizer2010.

In Western blotting, we found that wild-type p53 protein levels were expressed in an unstable manner except for the cells treated with alpinetin. We noticed that the expression of wild-type p53 protein is inconsistent with the level of p53 mRNA abundantly expressed in the cells. In Figure 2F, the subsequent decreased in the p53 protein after $72 \mathrm{~h}$ treatment at $50 \mu \mathrm{M}$ concentration of either curcumin or flavokawain $B$ is likely due to the instability of wild-type p53 protein. At physiological temperature, p53 protein have a short half-life of approximately $9 \mathrm{~min}$ and melting temperature of approximately $44^{\circ} \mathrm{C}$, thereby subjecting the protein to unstable conditions and subsequently suffer rapid protein denaturation (Boeckler et al., 2008). In response to alpinetin, the rate at which the cells retains the ability to sustain the p53 protein instability is not clear. Previously, treatment of cancer cells harbouring $\mathrm{R} 273 \mathrm{H}$ mutant p53 with different agents have been reported to stabilised p53 activity by either restoring the wild-type p53 activity resulting to its stabilisation (Bykov et al., 
2002a, 2005b; Tang et al., 2007; Zache et al., 2008;; Lambert et al., 2009, 2010; Zhao et al., 2010; Burmakin et al., 2013) or by restoring the sequence-specific DNA binding on the binding core domain of mutant p53 (Demma et al., 2010; Weinmann et al., 2008), or by downregulating the mutant p53 with minimal effect on the wild-type p53 (Li et al., 2011; Wang et al., 2011 ; Vakifahmetoglu-Norberg et al., 2013; Yi et al., 2013; Yan et al., 2014; Alexandrova et al., 2015; Zhang et al., 2015). Either way, the present study has preliminarily shown that the bioactive compounds under investigation are capable of restoring p53 functional activity in tumour cells expressing R273H mutant p53, however, subject to further investigation.

\section{CONCLUSION}

Findings from in vitro investigation strongly suggest the ability of curcumin, alpinetin and flavokawain B to influence R273 mutant p53, thereby causing direct expression of wide-type p53 protein essential in transactivation of target genes implicated in triggering cell cycle arrest and ultimately apoptosis induction.

\section{ACKNOWLEDGMENTS}

The authors will like to acknowledge the laboratory of UPM MAKNA-Cancer Research of Institute of Bioscience, Universiti Putra Malaysia where the research was carried out.

\section{Conflicts of Interest}

All authors declare no conflict of interest

\section{REFERENCES}

Alexandrova, E.M., Yallowitz, A.R., Li, D., Xu, S., Schulz, R., Proia, D.A., Lozano, G., Dobbelstein, M. and Moll, U.M. (2015). Improving survival by exploiting tumour dependence on stabilized mutant p53 for treatment. Nature, 523: 352-356.

Blandino, G. and Agostino, S. D. (2018). New therapeutic strategies to treat human cancers expressing mutant p53 proteins. Journal of Experimental \& Clinical Cancer Research, 37(1): 30 .
Boeckler, F.M., Joerger, A.C., Jaggi, G., Rutherford, T.J., Veprintsev, D.B. and Fersht, A.R. (2008). Targeted rescue of a destabilized mutant of p53 by an in silico screened drug. Proceedings of the National Academy of Sciences, 105:10360-10365.

Burmakin, M., Shi, Y., Hedström, E., Kogner, P. and Selivanova, G. (2013). Dual targeting of wild-type and mutant $p 53$ by small molecule RITA results in the inhibition of N-Myc and key survival oncogenes and kills neuroblastoma cells in vivo and in vitro. Clinical Cancer Research, 19: 5092-5103.

Bykov, V.J.N., Issaeva, N., Shilov, A., Hultcrantz, M., Pugacheva, E., Chumakov, P., Bergman, J., Wiman, K.G. and Selivanova, G. (2002a). Restoration of the tumor suppressor function to mutant p53 by a low-molecular-weight compound. Nature Medicine, 8:282-288.

Bykov, V.J.N., Issaeva, N., Zache, N., Shilov, A., Hultcrantz, M., Bergman, J., Selivanova, G. and Wiman, K.G. (2005b). Reactivation of mutant p53 and induction of apoptosis in human tumor cells by maleimide analogs. Biochemistry, 280:3 0384-30391.

Demma, M., Maxwell, E., Ramos, R., Liang, L., Li, C., Hesk, D., Rossman, R., Mallams, A., Doll, R., Liu, M., Seidel-Dugan, C., Bishop, W.R. and Dasmahapatra, B. (2010). SCH529074, a small molecule activator of mutant p53, which binds p53 DNA Binding Domain (DBD), restores growth-suppressive function to mutant p53 and interrupts HDM2-mediated ubiquitination of wild type p53. Journal of Biological Chemistry, 285:10198-10212.

Fridman, J.S. and Lowe, S.W. (2003). Control of apoptosis by p53. Oncogene, 22: 9030-9040. Joerger, A.C., Ang, H.C. and Fersht, A.R. (2006). tructural basis for understanding oncogenic p53 mutations and designing rescue drugs. Proceedings of the National Academy of Sciences, 103:15056-15061.

Joerger, A.C. and Fersht, A.R. (2016). The p53 Pathway: Origins, Inactivation in Cancer, and Emerging Therapeutic Approaches. Annual Review of Biochemistry, 85: 3753404. 
Lambert, J.M.R., Gorzov, P., Veprintsev, D.B., Söderqvist, M., Segerbäck, D., Bergman, J., Fersht, A.R., Hainaut, P., Wiman, K.G.and Bykov, V.J.N. (2009). PRIMA-1 Reactivates mutant p53 by covalent binding to the core domain. Cancer Cell, 15:376-388.

Lambert, J.M.R., Moshfegh, A., Hainaut, P., Wiman, K.G. and Bykov, V.J.N. (2010). Mutant p53 reactivation by PRIMA-1MET induces multiple signaling pathways converging on apoptosis. Oncogene, 29:1329-1338.

Li, D., Marchenko, N.D., Schulz, R., Fischer, V., Velasco-Hernandez, T., Talos, F. and Moll, U.M. (2011). Functional inactivation of endogenous MDM2 and CHIP by HSP90 causes aberrant stabilization of mutant p53 in human cancer cells. Molecular Cancer Research, 9: 577-588.

Li, J., Yang, L., Gaur, S., Zhang, K., Wu, X., Yuan, Y.C., Li, H., Hu, S., Weng, Y. and Yen, Y. (2014). Mutants TP53 p.R273H and p.R273C but not p.R273G enhance cancer cell malignancy. Human Mutation, 35: 575-584.

Malami, I., Abdul, A., Abdullah, R., Bt Kassim, N., Waziri, P. and Christopher Etti, I. (2016). In Silico Discovery of Potential Uridine-Cytidine Kinase 2 Inhibitors from the Rhizome of Alpinia mutica. Molecules, 21: 417.

Malami, I., Muhammad, A., Etti, I.C., Waziri, P.M. and Alhassan, A.M. (2017). An in silico approach in predicting the possible mechanism involving restoration of wild-type P53 functions by small molecular weight compounds in tumor cells expressing R273H mutant P53. EXCLI J. 16: 12761287.

Moos, P.J., Edes, K., Mullally, J.E. and Fitzpatrick, F.A. (2004). Curcumin impairs tumor suppressor p53 function in colon cancer cells. Carcinogenesis, 25:1611-1617.

Tan, B.S., Tiong, K.H., Choo, H.L., Fei-Lei Chung, F., Hii, L.-W., Tan, S.H., Yap, I.K., Pani, S., Khor, N.T., Wong, S.F., Rosli, R., Cheong, S.K. and Leong, C. O. (2015). Mutant p53$\mathrm{R} 273 \mathrm{H}$ mediates cancer cell survival and anoikis resistance through AKT-dependent suppression of BCL2-modifying factor (BMF).
Cell Death \& Disease, 6: e1826.

Tang, X., Zhu, Y., Han, L., Kim, A.L., Kopelovich, L., Bickers, D.R. and Athar, M. (2007). CP31398 restores mutant p53 tumor suppressor function and inhibits UVB-induced skin carcinogenesis in mice. Journal of Clinical Investigation, 117: 3753-3764.

Vakifahmetoglu-Norberg, H., Kim, M., Xia, H. guang, Iwanicki, M.P., Ofengeim, D., Coloff, J.L., Pan, L., Ince, T.A., Kroemer, G., Brugge, J.S. and Yuan, J. (2013). Chaperonemediated autophagy degrades mutant p53. Genes \& Development, 27:1718-1730.

Vijayakumaran, R., Tan, K.H., Miranda, P.J., Haupt, S. and Haupt1, Y. (2015). Regulation of mutant p53 protein expression. Frontiers in Oncology, 5: 284.

Wang, J., Zhao, Q., Qi, Q., Gu, H.Y., Rong, J.J., Mu, R., Zou, M.J., Tao, L., You, Q.D., Guo, Q.L. (2011). Gambogic acid-induced degradation of mutant p53 is mediated by proteasome and related to CHIP. Journal of Cellular Biochemistry, 112: 509-519.

Weinmann, L., Wischhusen, J., Demma, M.J., Naumann, U., Roth, P., Dasmahapatra, B. and Weller, M. (2008). A novel p53 rescue compound induces p53-dependent growth arrest and sensitises glioma cells to Apo2L/TRAIL-induced apoptosis. Cell Death and Differentiation, 15: 718-729.

Yan, W., Jung, Y.S., Zhang, Y. and Chen, X. (2014). Arsenic trioxide reactivates proteasome-dependent degradation of mutant p53 protein in cancer cells in part via enhanced expression of Pirh2 E3 ligase. PLoS One, 9: e0103497

Ye, M., Zhang, J., Zhang, J., Miao, Q., Yao, L. and Zhang, J. (2015). Curcumin promotes apoptosis by activating the p53-miR-192$5 p / 215-X I A P$ pathway in non-small cell lung cancer. Cancer Letters, 357:196-205.

Yi, Y., Kang, H., Kim, H., Kong, Y., Brown, M. and Bae, I. (2013). Targeting Mutant p53 by a SIRT1 Activator YK-3-237 Inhibits the Proliferation of Triple-Negative Breast Cancer Cells. Oncotarget, 4:1-10.

Zache, N., Lambert, J.M.R., Rökaeus, N., Shen, J., 
Hainaut, P., Bergman, J., Wiman, K.G. and Bykov, V.J.N. (2008. Mutant p53 targeting by the low molecular weight compound STIMA1. Molecular Oncology, 2:70-80.

Zhang, S., Zhou, L., Hong, B., Van Den Heuvel, A.P.J., Prabhu, V. V., Warfel, N.A., Kline, C.L.B., Dicker, D.T., Kopelovich, L. and ElDeiry, W.S. (2015). Small-molecule NSC59984 restores p53 pathway signaling and antitumor effects against colorectal cancer via p73 activation and degradation of mutant p53. Cancer Research, 75:38423852.
Zhao, C.Y., Grinkevich, V. V., Nikulenkov, F., Bao, W. and Selivanova, G. (2010). Rescue of the apoptotic-inducing function of mutant $\mathrm{p} 53$ by small molecule RITA. Cell Cycle, 9:18471855.

Zhao, Y., Aguilar, A., Bernard, D. and Wang, S. (2015). Small-molecule inhibitors of the MDM2-p53 protein-protein interaction (MDM2 inhibitors) in clinical trials for cancer treatment. Journal of Medicinal Chemistry, 58:1038-1052. 